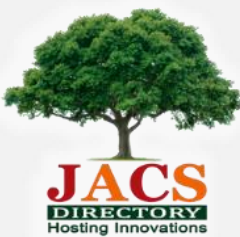

Journal of Nanoscience and Technology

\title{
Silver Nanoparticles: The Powerful Antidote for Disease in Pomegranate
}

\author{
A.S. Sherkhane1,2,*, H.H. Suryawanshi1 ${ }^{1}$, A.A. Daspute ${ }^{2}$, A.A. Bhosale ${ }^{3}$, R.J. Sharma ${ }^{1}$, B.P. Shinde ${ }^{1}$ \\ ${ }^{1}$ Department of Biotechnology, Vidya Pratishthan's Arts, Science and Commerce College, Baramati, Pune - 413 133, Maharastra, India. \\ ${ }^{2}$ Department of Agri- Biotechnology, Vidya Pratishthan's College, Baramati, Pune - 413 133, Maharastra, India. \\ ${ }^{3}$ Department of Microbiology, Vidya Pratishthan's Arts, Science and Commerce College, Baramati, Pune - 413 133, Maharastra, India.
}

\section{A R T I C L E D E T A I L S}

Article history:

Received 17 December 2018

Accepted 09 February 2019

Available online 05 March 2019

Keywords:

Pomegranate

Bacterial Blight Disease

Xanthomonas axonopodis

Silver Nanoparticles

\begin{abstract}
A B S T R A C T
In this study, simple approach was applied for the synthesis, characterization and application of silver nanoparticles from the leaves of Bryophyllum $p$., garlic and jamun which is cost-effective, eco-friendly and easy to synthesis. The extract acts both as reducing as well as capping agent. The color change of the solution yellowish brown to reddish brown confirms the formation of silver nanoparticles. The synthesized silver nanoparticles were characterized by UV-visible spectroscopy which showed a peak between 420 and $430 \mathrm{~nm}$ corresponding to the absorbance of the AgNPs that confirmed the reduction of $\mathrm{Ag}^{+}$to $\mathrm{Ag}^{0}$ nanoparticles. The anti-bacterial activity of AgNPs was investigated against Xanthomonas axonopodis pv. punicae and its identity was confirmed by morphological, biochemical and pathogenicity test. The results indicated that garlic AgNPs shoed maximum inhibition at a concentration of $15 \mathrm{mM}$. Hence, they can be used in the disease management in pomegranate.
\end{abstract}

\section{Introduction}

Recently, nanotechnology is rapidly growing field with great application for generating nanoparticles by using medicinal plants in agriculture due to their diverse effect [1]. Silver nanoparticles of size smaller than $100 \mathrm{~nm}$ contain about 10,000-15,000 silver atoms [2]. It has various role in field of high sensitivity bimolecular detection, catalysis [3] and medicine; it is been acknowledged to have strong bactericidal effects along with the anti-fungal activities [4-6]. Silver nanoparticles have showed to be the most effective against bacteria and some eukaryotic micro-organisms. The synthesis of nanoparticles by biological method showed better results than the chemical methods, it is easily scaled up and cost effective [7]. Biosynthetic methods can use microorganism or the plant extract for production of nanoparticles [8]. Pomegranate is one of the known edible fruit [9], growing in tropical and subtropical regions, belongs to the Punicaceae family. In recent years the area under pomegranate has been increased due to low maintenance costs, drought resistance and high yields. It is rich in vitamin $C$, antioxidants $[10,11]$ and containing polyphenols which inhibit estrogen synthesis. In India, pomegranate is commercially cultivated in Maharashtra, Karnataka, Andhra Pradesh, Gujarat, Uttar Pradesh, and Tamil Nadu [12]. There are several production constraints of pomegranate crop which severe yield losses among them bacterial blight diseases caused by Xanthomonas axonopodis pv. Punicae; a major threat $[13,14]$. Initial symptoms showed small irregular water soaked, dark colored spots on leaves which later on enlarge and led to defoliation, result in heavy economic losses and complete destruction [15]. In the present study the causative agent was isolated from the infected fruits and to control of this disease, silver nanoparticles were synthesized from leaf extracts of Bryophyllum p. garlic and jamun at variable concentrations. The results were confirmed by UVvisible spectroscopy and antimicrobial activity of silver nanoparticles was evaluated against bacterial blight disease to control and manage disease which will be beneficial to farmers.

\section{Experimental Methods}

\subsection{Sample Collection}

The infected fruit samples were collected from the farmer's fields of major pomegranate growing areas of Bori, Indapur, Maharashtra (India), showing typical symptoms like yellowish brown spots, water-soaked lesions, cankers lesions and brown patches (Fig. 1). Higher disease infected fruits were selected according to disease severity scale [16].

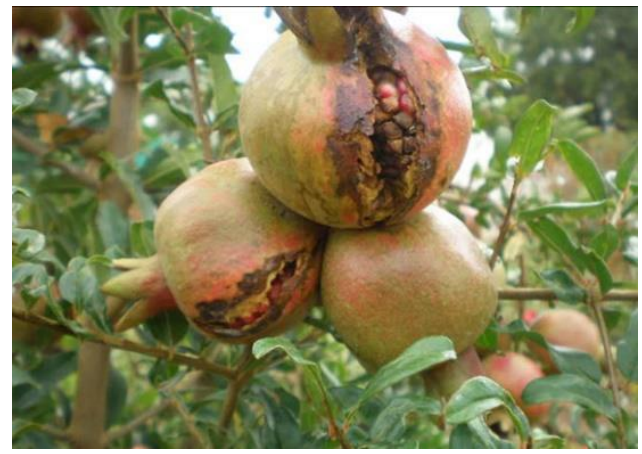

Fig. 1 Xanthomonas sp.III Sample collection of infected fruit from the areas of Bori Indapur, Maharashtra (India)

\subsection{Isolation and Characterization of Pathogen}

Infected fruit samples were collected; surface sterilized with $0.1 \%$ $\mathrm{HgCl}_{2}$ solution for 1 minute and washed three times with sterile distilled water. Then it was squeezed gently with a sterile scalpel to get a suspension. The suspension was serially diluted and plated in sterilized petriplates containing YDC agar medium and incubated at $30{ }^{\circ} \mathrm{C}$ for 72 hours. After the incubation, isolates were showing typical characters of Xanthomonas axonopodis with light yellow mucoid shining colonies (Fig. 2). The isolated colonies of $X$. axonopodis were named as isolate III based on disease severity scale. Further isolated colonies were screened based on biochemical and morphological characterization according to $9^{\text {th }}$ edition of Bergey's manual of Determinative Bacteriology [17].

\subsection{Pathogenicity Test}

Pathogenicity tests were performed of isolates III. For this the healthy pomegranate fruit was selected, surface sterilized with $10 \%$ sodium 
hypochlorite for 1 minute. Fruit were priced by a sterile needle and sprayed with suspension of Xanthomonas axonopodis isolates as per their same fruit variety. The inoculated fruit packed with sterile polythene bags. Disease symptoms were observed after 10-15 days. The pathogens were reisolated from the diseased fruits and compared with their original cultures for their verification [18-20].

\subsection{Synthesis of Silver Nanoparticles by using Plant Extracts}

$5 \mathrm{~g}$ of fresh Bryophyllum $p$. garlic and jamun leaves were collected from the bio-village of VPASC College, Baramati. The leaves were crushed in deionized water; the extract was filtered by Whatman filter paper number one. The $5 \mathrm{~mL}$ of extract filtrate was collected and added in various concentrations of silver nitrate solution ( $5 \mathrm{mM}, 10 \mathrm{mM}$ and $15 \mathrm{mM})$. This reaction was kept under dark condition for 15 days; tubes were monitored after every 24 hours. After 15 days, the color change of the solution containing silver nanoparticles was analyzed by UV spectroscopy. Reaction showing peaks at around $420 \mathrm{~nm}-430 \mathrm{~nm}$. This solution was centrifuged at $10,000 \mathrm{rpm}$ for $10 \mathrm{~min}$ and the precipitate of silver nanoparticles was washed in methanol three times. The resulting pellet was dried in oven at $65^{\circ} \mathrm{C}$ for 24 hours and then collected for further use.

\subsection{In-vitro Efficiency of Biosynthesized Silver Nanoparticles against}

\section{Xanthomonas axonopodis Isolates}

The antibacterial test was carried out by agar well diffusion method on nutrient agar medium [21]. Different concentration of silver nanoparticles was prepared in Erlenmeyer flasks. For antimicrobial activity freshly prepared $100 \mu \mathrm{L}$ of the isolated pathogen was spread on the sterile nutrient agar plates. The milli-Q water and silver nanoparticles were used as a positive control; Bryophyllum $p$. garlic and jamun used as a test sample. Plates were incubated at $37^{\circ} \mathrm{C}$ for 24 hours, and then the zone of inhibition was measured.

\section{Results and Discussion}

\subsection{Colony Characteristics}

After the incubation, Xanthomonas $s p$. III isolates was showing typical characters with light yellow mucoid shining colonies (Fig. 2).

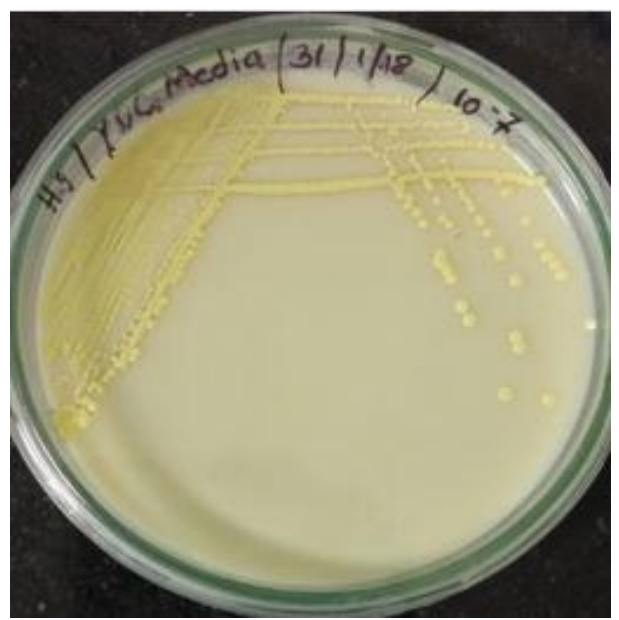

Fig. 2 The results of isolates Xanthomonas sp. III on YDC agar plates

Table 1 Colony characters of isolate Xanthomonas sp. III

\begin{tabular}{ll}
\hline Colony characters & Xanthomonas sp. III \\
\hline Size & $3 \mathrm{~mm}$ \\
Shape & Circular \\
Colour & Yellow \\
Margin & Regular \\
Elevation & Elevated \\
Consistency & mucoid \\
Opacity & Opaque \\
Gram nature & Gram Negative rods \\
Motility & Motile \\
\hline
\end{tabular}

\subsection{Biochemical Characteristics of Isolates Xanthomonas sp. III}

The biochemical characters of isolate Xanthomonas sp. III, are given in Table 1. Identification of isolates was done by comparing morphological and biochemical tests according to Bergy's manual (Fig. 3).

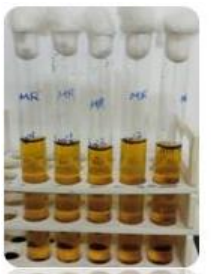

Methyl Red Test -ve
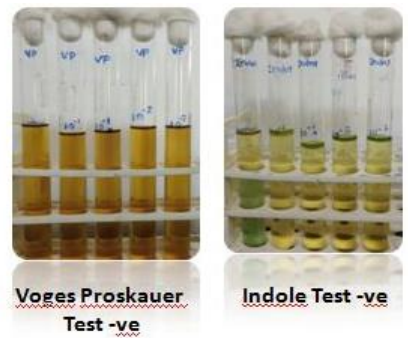

Indole Test -ve

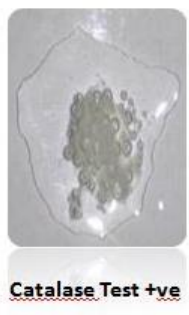

Fig. 3 Biochemical tests for identification of isolates

\subsection{Pathogenicity Test}

Pathogenicity tests were performed on the field of VSBT farm. For this the healthy pomegranate fruit were selected, surface sterilized with $10 \%$ sodium hypochlorite. Pomegranate were priced by a sterile needle and sprayed with suspension of Xanthomonas axonopodis isolates as per their same fruit variety. The inoculated fruits packed with sterile polythene bags. After 15-25 days observation shows the development of disease symptoms. The pathogens were reisolated from the diseased fruits and compared with their original cultures for their verification (Fig. 4).

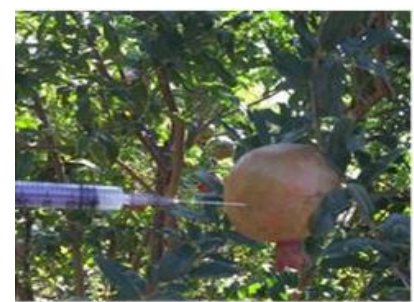

a)

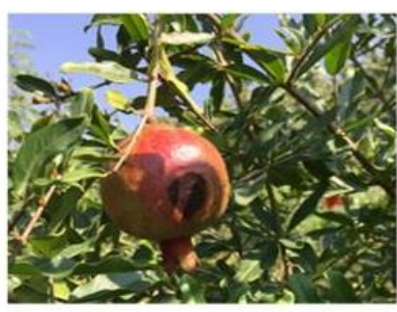

b)
Fig. 4 Pathogenicity test of Xanthomonas spp.III a) Inaculation of X.axonopodis pv.Punicae on pomegranate plant b) Symptoms of bacterial blight observed on fruits after 15-25 days of incubation

\subsection{Synthesis of Silver Nanoparticles}

As the leaf extracts were added to different concentrations of aqueous silver nitrate solution, the color of the solution changed from colourless to brown indicating AgNP formation (Fig. 5). The completion of reaction between leaf extract and $\mathrm{AgNO}_{3}$ was observed. Absorption spectra of AgNPs formed in the reaction media has absorption maxima in the range of 420 to $460 \mathrm{~nm}$ (Fig. 6).

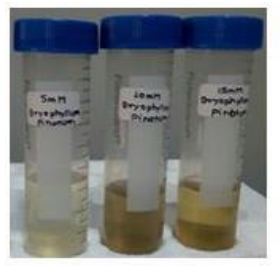

Brvophyllump.

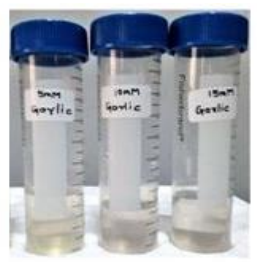

Garlic

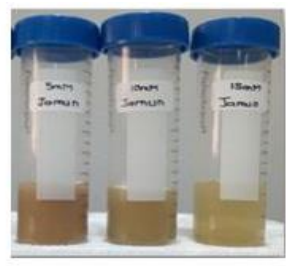

Jamun
Fig. 5 Silver Nanoparticles of garlic, Bryophyllum p. and jamun

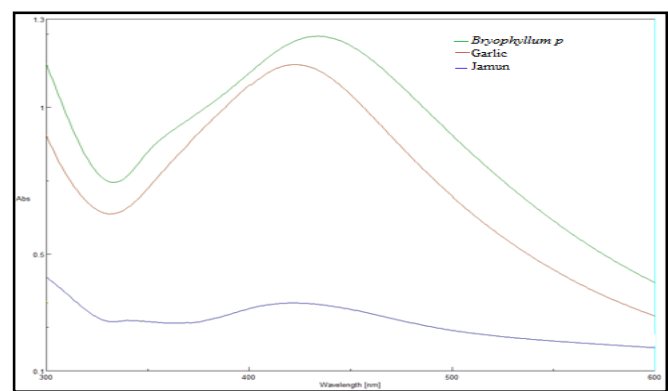

Fig. 6 Spectral analysis of silver nanoparticles at 420 to $430 \mathrm{~nm}$

\subsection{Anti-Microbial Activity of Extract}

The antimicrobial activity shows most rapid bioreduction in $5 \mathrm{~mL}$ extract of Bryophyllum p. garlic and jamun at $15 \mathrm{mM}$ concentration of silver nitrate solution. Among three medicinal plant extract, garlic extract is a good source for the synthesis of silver nanoparticles to overcome the problems of bacterial blight of pomegranate. The inhibition zones obtained indicates maximum antibacterial activity of the prepared test sample (Figs. 7, 8). The silver nanoparticles produced by tulsi, neem, tridax 
and drumstick showed the inhibition of Xanthomonas sp. [22] where the different cyanobacterial stains also produced extracellular silver nanoparticles and these nanoparticles have an antibacterial activity [23].
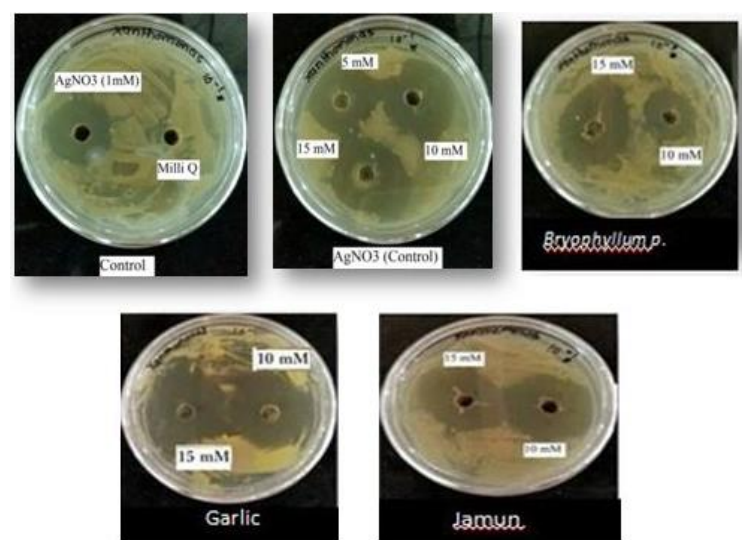

Fig. 7 Antibacterial activity of control, $\mathrm{AgNO}_{3}$ (control), Bryophyllum p. garlic and jamun at (10mM conc.) against Xanthomonas axonopodis pv. punicae

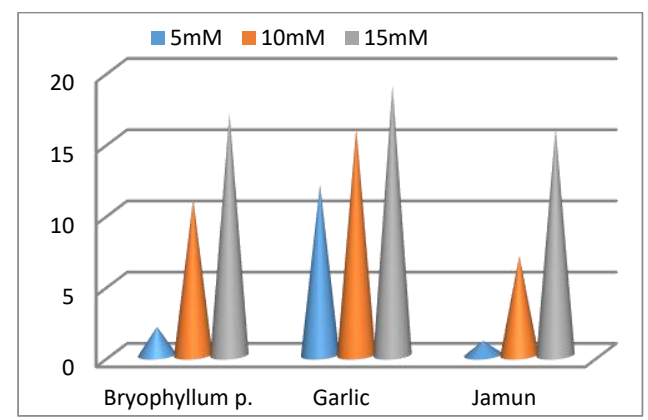

Fig. 8 Antimicrobial activity of AgNP's, against Xanthomonas sp. III at different concentration

\section{Conclusion}

Present study results showed that, bacterial blight of pomegranate was found to be highly destructive and wide spread disease. Xanthomonas $s p$. III was obtained from the highly infected plant and its identity was confirmed by morphological, biochemical and Pathogenicity tests. We found that garlic extract is a good source for the synthesis of silver nanoparticles to overcome the problems of bacterial blight of pomegranate. Therefore, silver nanoparticles would be used as powerful weapons against Xanthomonas axonopodis pv. punicae.

\section{Acknowledgements}

Authors are thankful to the Principal, Vidya Pratishthan's Art, Science and Commerce College, Baramati; Principal, Vidya Pratishthan's School of Biotechnology; Head, Department of Microbiology and also Head, Department of Biotechnology for providing necessary facilities and constant help during the research period.

\section{References}

[1] E.I. Chaghaby, A.F. Ahmad, Biosynthesis of silver nanoparticles using Pistacia lentiscus leaves extract and investigation of their antimicrobial effect, Oriental J. Chem. 27 (2011) 929-936.

[2] G. Oberdorster, A. Maynard, K. Donaldson, V. Castranova, J. Fitzpatrick, K Ausman, Nanotoxicology: an emerging discipline evolving from studies of ultrafine particles, Part. Fibre Toxicol. 2 (2005) 38-43.

[3] Z.J. Jiang, C.Y. Liu, L.W. Sun, Catalytic properties of silver nanoparticles supported on silica spheres, J. Am. Chem. Soc. 71 (2004) 2341-2343.

[4] K.K. Mondal, J. Sharma, Bacterial blight: an emerging threat to pomegranate export, Indian Farm. 59 (2009) 22-23.

[5] Julia Jurenka, Therapeutic applications of pomegranate (Punica granatum L.): A review, Alt. Med. Rev. 13 (2008) 128-144.

[6] S.A. Naqvi, M.S. Khan, S.B. Vohora, Antibacterial, antifungal, antihelminthic investigations on Indian medicinal plants, Fitoterapia 62 (1991) 221-228.

[7] P. Gong, H. Li, X. He, K. Wang, J. Hu, W. Tan, S. Tan, X.Y. Zhang, Preparation and antibacterial activity of $\mathrm{Fe}_{3} \mathrm{O}_{4} @ \mathrm{Ag}$ nanoparticles, Nanotechnol. 18 (2007) 604611.

[8] R. Sathyavathi, M.B. Krishna, S.V. Rao, R. Saritha, D.N. Rao, Biosynthesis of silver nanoparticles using Coriandrum sativum leaf extract and their application in nonlinear optics, Adv. Sci. Lett. 3(2010) 1-6.

[9] A.B. Damania, The pomegranate: Its origin, folklore, and efficacious medicinal properties, In: Agri. heritage of Asia - Proc Int. Conf. 1 (2005) 175-183.

[10] N.K. Malhotra, H.N. Khajuria, Studies on physico-chemical characters of pomegranate cultivars, Punjab Hort. J. 23 (1983) 158-161.

[11] Y. Li, C. Guo, J. Yang, J. Wei, J. Xu, S. Cheng, Evaluation of antioxidant properties of pomegranate peel extract in comparison with pomegranate pulp extract, Food Chem. 96 (2006) 254-260.

[12] K.L. Chadha, Pomegranate, In: Handbook of horticulture, (Eds.): Shashi A. Verma and Somdutt, Directorate of Information and Publications of Agriculture, ICAR, New Delhi, India, 2001, p.297,

[13] Y. Petersen, E.L. Mansvelt, E. Venter, W.E. Langenhoven, Detection of Xanthomonas axonopodis pv. punicae causing bacterial blight on pomegranate in South Africa, Austr. Plant Pathol. 39 (2010) 544-546.

[14] L. Vauterin, B. Hoste, K. Kersters, J. Swings, Reclassification of xanthomonas, Int. J. Syst. Bacteriol. 45 (1995) 472-489.

[15] J. Sharma, K.K. Sharma, A. Kumar, K.K. Mondal, S. Thalor, et al., Pomegranate bacterial blight: symptomatology and rapid inoculation technique for Xanthomonas axonopodis pv. Punicae, Jour. Plant Pathol. 99 (2017) 109-119.

[16] Anonymous, Survey methodology for bacterial blight of pomegrante, NRCP Publication, Solapur, India, 2006.

[17] G. Garrity, D.J. Brenner, N.R. Krieg, J.R. Staley, The proteobacteria, Bergey's manual ${ }^{\circledR}$ of systematic bacteriology, Vol. 2, Springer, New York, 2007.

[18] K.S. Raghuwanshi, B.A. Hujare, V.P. Chimote, S.G. Borkar, Characterization of Xanthomonas axonopodis $p v$. punicae isolates from Western Maharashtra and their sensitivity to chemical treatments, The Bioscan. 8 (2013) 845-850.

[19] P.B. Kale, V.P. Chimote, K.S. Raghuwanshi, A.A. Kale, A.S. Jadhav, S.G. Borkar, Microbial, biochemical, pathogenicity and molecular characterization of Xanthomonas axonopodis pv. Punicae from pomegranate, J. Pure Appl. Microbiol. 6 (2012) 1699-1706.

[20] N.P. Chavan, R. Pandey, N. Nawani, G.D. Tandon, M.B. Khetmalas, Genetic variability within Xanthomonas axonopodis pv. punicae, Causative agent of oily spot disease of pomegranate, J. Plant Pathol. Microbiol. 8 (2017) 1-6.

[21] J.H. Jorgensen, J.D. Turnidge, J.A. Washington, Antibacterial susceptibility tests: dilution and disk diffusion methods. in Manual of clinical microbiology, Eds. P.R. Murray, E.J. Baron, MA. Pfaller, F.C. Tenover, R.H. Yolken, American Society for Microbiology, Washington, DC. 7 (1999) 1526-1543.

[22] A.S. Sherkhane, H.H. Suryawanshi, P.S. Mundada, B.P. Shinde, Control of bacterial blight disease of pomegranate using silver nanoparticles, J. Nanomed. Nanotechnol. 9 (2018) 1-5.

[23] S. Pawar, A. Bhosale, P. Mulani, P. Patekar, S. Shaha, Screening of silver nanoparticles producing cyanobacteria and its characterization, Int. Res. J. Sci. Eng. A1 (2017) 44-54. 